\title{
Waste management in the Irkutsk Region, Siberia, Russia: Environmental assessment of current practice focusing on landfilling
}

Starostina, Vlada; Damgaard, Anders; Rechberger, Helmut; Christensen, Thomas Højlund

Published in:

Waste Management and Research

Link to article, DOI:

$10.1177 / 0734242 X 14526633$

Publication date:

2014

Document Version

Peer reviewed version

Link back to DTU Orbit

Citation (APA):

Starostina, V., Damgaard, A., Rechberger, H., \& Christensen, T. H. (2014). Waste management in the Irkutsk Region, Siberia, Russia: Environmental assessment of current practice focusing on landfilling. Waste Management and Research, 32(5), 389-396. https://doi.org/10.1177/0734242X14526633

\section{General rights}

Copyright and moral rights for the publications made accessible in the public portal are retained by the authors and/or other copyright owners and it is a condition of accessing publications that users recognise and abide by the legal requirements associated with these rights.

- Users may download and print one copy of any publication from the public portal for the purpose of private study or research.

- You may not further distribute the material or use it for any profit-making activity or commercial gain

- You may freely distribute the URL identifying the publication in the public portal 


\title{
Waste management in the Irkutsk Region, Siberia, Russia: Environmental assessment of current practice focusing on landfilling
}

\author{
Vlada Starostina ${ }^{1 *}$, Anders Damgaard ${ }^{2}$, Helmut Rechberger ${ }^{3}$ \& Thomas H. Christensen $^{2}$ \\ ${ }^{1}$ Department of Mineral Processing and Engineering Ecology, National Research Centre, \\ Irkutsk State Technical University, Irkutsk, Russia \\ ${ }^{2}$ Department of Environmental Engineering, Technical University of Denmark, Lyngby, Denmark \\ ${ }^{3}$ Institute of Water Quality, Resource, and Waste Management, Vienna University of Technology, Vienna, \\ Austria
}

*Corresponding author: email: vladastarostina@yandex.ru

"NOTE: this is the author's version of a work that was accepted for publication in Waste Management \& Research journal. Changes resulting from the publishing process, such as peer review, editing, corrections, structural formatting, and other quality control mechanisms may not be reflected in this document. Minor changes may have been made to this manuscript since it was accepted for publication. A definitive version is published in Waste management \& research, vol 32(5), pp 389-396, doi: 10.1177/0734242X14526633" 


\begin{abstract}
The municipal waste management system of the region of Irkutsk is described and an LCA performed to assess the environmental performance of the system. Annually about 500000 tons waste are managed. The waste originates from three sources: Household Waste (27\%), Commercial waste (23\%) and Office \& Institutional Waste (44\%). Other waste of unknown composition constitutes $6 \%$. Only $3 \%$ of the waste is recycled; $97 \%$ of the municipal waste is disposed of at the old Alexandrovsky landfill. The environmental impact from the current system is dominated by the landfill which has no gas or leachate collection system. The Global Warming contribution is due to the emission of methane of the order of 420000 tons $\mathrm{CO}_{2}-$ equivalents per year. Collection and transport of the waste are insignificant compared to impacts from the landfill. As the old landfill runs out of capacity in a few years, the LCA modeling showed that introduction of a new and modern landfill with gas and leachate collection could improve the performance of the waste management system significantly. Collection of landfill gas and utilization for 30 years for electricity production (gas turbine) would reduce the Global Warming completely and result in a net saving of 100000 $\mathrm{CO}_{2}$-equivalents per year due to storage of biogenic carbon in the landfill beyond 100 years. Considering other first-order degradation rates for the landfilled organic matter did not affect the results much, while assumptions about the top cover oxidation of methane significantly affected the results. This shows the importance of controlling the gas escape from the landfill.
\end{abstract}

Key words: Waste, Siberia, LCA, landfill improvement 


\section{Introduction}

Irkutsk is the center of Eastern Siberia, Russia. About 590000 inhabitants live in the city; this corresponds to $21 \%$ of all people living in Eastern Siberia (about $7.210^{6} \mathrm{~km}^{2}$ ). Waste management in Irkutsk currently is based on landfilling of the municipal waste; only $3 \%$ of the waste is recycled. Most of the waste is landfilled at the Alexandrovsky landfill, but in view of increasing amounts of waste and the limited remaining capacity of this landfill, alternative management schemes must soon be developed. These alternatives may include increasing material recycling, incineration, mechanical-biological treatment and sanitary landfilling or combinations hereof. The situation in Irkutsk is typical for major parts of Russia: The long established use of simple landfills as the only waste management option is no longer appropriate with the increasing environmental concerns and the focus on saving of resources.

In a recent paper addressing the household and commercial waste also in the Irkutsk region (Tulokhonova \& Ulanova, 2013), an LCA-screening combined with social and economic estimates suggested that the current waste management system easily could be improved, but that this also would increase cost significantly. The LCA modeling was performed with an older LCA model (LCA-IWM from 2005; den Boer et al., 2007) using standard European waste technologies not necessarily representing technologies relevant in Siberia. This may be acceptable for a screening process, but it is insufficient for a closer evaluation of the environmental impacts from alternative development scenarios. The value of performing LCA modeling is closely linked to the ability of modeling the actual technologies and defining realistic alternative scenarios.

This paper provides a systematic inventory and an environmental assessment of the current waste management system in Irkutsk using life-cycle-assessment (LCA). We modeled the local technologies by using a new LCA-model (EASETECH; see later) which allows for defining specific technologies relevant for the actual study. This assessment can serve as a basis for developing alternative management schemes with improved environmental performance. This paper also investigates how better landfill technology can improve the environmental performance, while a second paper (Starostina et al., 2014) investigates the environmental benefits of introducing increased recycling and other treatment of the residual waste than by landfilling.

LCA has gained increasing importance in assessing waste management systems, e.g. Christensen et al. (2007) and Gentil et al. (2010), because of its ability to provide systematic accounts of the environmental potential impacts of complex waste management systems. LCA provides a possibility of ranking alternative management approaches from an environmental perspective and thus should be used in planning of new waste management or in developing existing systems.

\section{Materials and methods}

\subsection{Inventory}

The inventory of the current waste management system in Irkutsk is based on various official reports from the regional authorities and from studies performed by students and faculty of the State Technical University in Irkutsk. Where data are limited or lacking regarding the Irkutsk region, supplementary information has been obtained from the literature.

\subsection{STAN}


The mass and substance flow model STAN (Cencic \& Rechberger, 2008) was used to estimate the composition of the two main waste types constituting the municipal solid waste (MSW). Data were available in terms of amounts and composition of the Household Waste and the Commercial, Office \& Institutional Waste generated in Irkutsk, as well as amount and composition of the MSW entering the Alexandrovsky landfill. The data from the sampling of the waste entering the landfill was more detailed than the data from the point of generation. STAN was thus used to calculate the composition at the point of generation, through assumptions on where each fraction most likely originated from. As an example it was assumed that the majority of newspaper was from the Household Waste (initial estimate: $3 \%$ ), that cardboard (initial estimate: 13\%) and plastic (initial estimate: 17\%) were primarily from Commercial, Office \& Institutional Waste. STAN calculated the composition of the two waste types while minimizing the deviations from the observations.

\section{3. $L C A$}

The EASETECH model (Damgaard et al., 2013) was used in the LCA modeling. This model is a new version of the well-proven waste LCA waste model EASEWASTE (Kirkeby et al., 2006a) which has been used in many studies on waste management systems under a range of different conditions, e.g. in China (Zhao et al. 2010), California, USA (Vergara et al, 2011), Greenland (Eistedt \& Christensen, 2013) and Denmark (Larsen et al., 2010).

The environmental impact assessment is done according to the EU-JRC's recommendations for Life Cycle Impact Assessment in a European context (European Commission, 2011) since there is no specific assessment method for Russia. The normalization references for the suggested method has still not been released, and it was therefore decided only to use a subset of the impacts included in the recommendation for which we could access normalization references. The chosen impact categories and their associated normalization reference are presented in Table 1. The normalization reference expresses the potential impact from all activities in the life (food, housing, transport, etc.) of one person in one year.

Many assumptions have been made in order to provide a full inventory of the waste management system in Irkutsk. This has called for sensitivity analyses in order to assess the robustness of our environmental assessment. The robustness of the LCA modeling was examined according to the tiered approach suggested by Clavreul et al. (2012.

\section{Results and discussion}

The results are presented in terms of the inventory of the waste management system in Irkutsk followed by the LCA impact assessment. The discussion focusses on the robustness of the assessment and the lessons learned.

\subsection{Inventory}

\section{Municipal waste: amount and composition}

The municipal solid waste (MSW) in Irkutsk in 2011 constituted approximately 500000 tons according to the public records (MNREIR, 2012). The waste can be grouped into four groups: Household Waste, Commercial Waste, Office \&Institutional Waste, and Others. 
The Household Waste is generated in 6559 multi-family houses hosting about $90 \%$ of the population and in 19500 single-family houses hosting about $10 \%$ of the population. The annual waste generation is approximately $230 \mathrm{~kg}$ per person (MOI, 2008), corresponding to 136000 tons per year. The household waste constitutes about $27 \%$ of the MSW.

The Commercial Waste is generated by approximately 24000 units including shops, restaurants, and small workshops. The amount of commercial waste has not been determined specifically for Irkutsk, however, the regional authorities have estimated that 114000 tons of commercial waste is generated annually (DEPAI, 2007). The commercial waste is collected as part of the municipal waste except for 8500 tons of paper and 7500 tons of glass which are collected separately for recycling. Commercial waste constitutes about $23 \%$ of the MSW.

The Office \& Institutional Waste consists of common waste from offices, public administration, educational institutions, sport facilities etc. and are estimated on basis of general data DEPAI (2007) to amount to 220000 tons yearly or $44 \%$ of the MSW.

Other Waste amounts to approximately 30000 tons per year or $6 \%$ of the MSW. Its nature and composition is not reported.

The MSW composition in Irkutsk has been studied several times by students and faculty at the State Technical University in Irkutsk by sampling of the waste received at the landfill. Trucks have randomly been sampled, the waste sorted manually, and the various fractions weighted. The waste composition is presented in Table 2. Combined with general data on the composition of commercial and institutional waste it has been possible by using the material flow analysis model STAN to estimate the composition of the Household Waste and the combined Office, Commercial \& Institutional Waste; see Table 3.

\section{Waste collection and transport}

The MSW is collected in common bins (typically $0.75 \mathrm{~m}^{3}$ containers) for the multi-family house and the private houses. The bins are emptied every day, every second day or twice a week depending on the need and the season.

The diesel consumption of the collection trucks has been measured and is in average 44 I per round trip including collection, driving to the landfill located $10 \mathrm{~km}$ from the city center, unloading and returning to the city. According to data from the landfill based on weighting of in-going and out-going trucks, a truck typically contains 8-9 tons of waste. The observed diesel consumption equals $5.0-5.5$ I per ton of waste collected and transported to the landfill. This corresponds in the EASETECH model to a use of diesel of $4.5 \mathrm{I}$ diesel per ton of waste for collection of the waste and use of $0.1 \mathrm{I}$ of diesel per ton and $\mathrm{km}$ (one way distance) for transport of the waste to the landfill after collection. The diesel consumption is about the same as reported in a Danish study (Larsen et al., 2009). It is reasonable to distinguish between the collection and the transport since a new landfill may be located further away from the city. The exhaust emissions from the trucks have not been measured; we assume that emissions correspond to a EURO3 standard. This has implications for most impact categories except Global Warming.

\section{Recycled materials}

We have little information about the destiny of the recycled materials. We assume that the paper and glass is traded on the market and used for direct recycling into new products. We assume an average transport distance to the recycling industries of $1000 \mathrm{~km}$. Standard recycling processes in EASETECH are used for the 
LCA modeling. A second paper (Starostina et al, 2013) where increased material recycling is examined provides more details about how the recycling is seen and modeled within the Irkutsk region.

\section{Landfilling -existing facility}

The Alexandrovskiy landfill is located $10 \mathrm{~km}$ from the city center of Irkutsk. The landfill area is $420000 \mathrm{~m}^{2}$ and the average filling depth is $30 \mathrm{~m}$. The bulk density is estimated to 0.67 ton $\mathrm{m}^{-3}$ since compaction is by dozer. The landfill receives annually approximately 500000 tons of MSW and the capacity is expected to be exhausted within 5-6 years. The landfill was constructed in 1963 and has no leachate and no gas collection system. Completed sections are cover by soil and vegetation.

The leachate generation is not known, but an estimate can be obtained from general data on annual precipitation $(465 \mathrm{~mm}$ ) and actual evapotranspiration (350 mm) (ROSHYDROME, 2012). The landfill is covered by snow typically from November to April, and the geometry of the landfill surface as well as the weather during spring affect how much of the melt water penetrates into the landfill body and how much runs off on the surface without being in contact with the waste. The annual leachate generation is likely to be $150-250 \mathrm{~mm}$. The leachate composition has not been measured since leachate is not collected and we have used general data based on world-wide landfill leachate data (originates from Manfredi \& Christensen, 2009) with adjustments for selected parameters to Russian data relevant for landfills in cold regions (Gonopolsky et al.,2009; Zomarev, 2007; Potapov, 2004). The assumptions made corresponds to an accumulated leaching ration of 1-2 (L/S: $\mathrm{m}^{3}$ of leachate per ton of dry waste landfilled) for a period of 100 years.

The gas generation and composition is estimated by the EASTECH model using a first order degradation model for each of the organic fractions characterized in Table 4. Kinetic constants are set for colder climates and are based on De la Cruz \& Barlaz (2010), where the fraction-specific constants are assumed to be similar to a dry climate. The model estimates a total methane generation of $86 \mathrm{~m}^{3}$ per ton of waste for a 100 year period. We assume that the top cover of the completed sections have the ability to oxidize some of the methane to carbon dioxide. However, experimental data are few (reviewed by Scheutz et al., 2009), and almost lacking for landfills in very cold climates. We assume that $20 \%$ of the methane is oxidized. The oxidation rate is considered low because the methane flux out of the landfill is relative high since no gas is collected; the flux is however expected to decrease later in the life of the landfill. As the gas generation goes down it is likely that the top cover becomes relatively better in oxidizing the gas. However, these assumptions are not well supported and the importance of this parameter should be quantified in the sensitivity analysis.

\section{Landfilling -new facility}

As the capacity of the existing landfill soon will be exhausted, a new landfill is likely to be established as part of the future waste management system. We investigate how the environmental profile of the waste management system would be with a new modern landfill with up-to-date environmental technology to control gas and leachate. We assume that the waste landfilled has the same composition as in the early part of this study: this means that the gas generation is unchanged as is the leachate generation. However, changes are introduced in terms of the way the gas and leachate are managed:

- Gas is collected during the first 30 years after landfilling of the waste with an efficiency of $80 \%$. The collected gas is used in a gas turbine for electricity production. We assume that the generated electricity distributed to the grid will substitute for electricity produced by coal, which is the 
marginal fuel for electricity in the Irkutsk region. A major part of the regional electricity is produced as hydro-power but this is not expected to be marginal on an annual basis. The remaining gas is escaping through the soil cover of the landfill while subject to $50 \%$ oxidation of the methane. The fact that the flux of escaping methane now is low allows for assuming a higher methane oxidation rate in the top cover compared to the oxidation rate representing the old landfill.

- Gas is after 30 years after landfilling of the waste no longer collected for energy generation due to too low a flux to run a gas turbine. The gas is however collected and flared for the next 10 years; thereafter the gas is it not collected actively but assumed to escape through the landfill cover while subject to $50 \%$ oxidation of the methane.

- Leachate is collected with an efficiency of $95 \%$ for the first 50 years and with an efficiency of $80 \%$ for the remaining 50 years, as we assume that the liner as well as the drainage system will be less efficient with time. The collected leachate is treated (EASETECH data) and discharged to surface waters while the uncollected leachate is assumed to reach the groundwater aquifer.

\section{$3.2 L C A$ results}

\section{The current waste management system - old landfill}

The current waste management system in the Irkutsk region is for all impact categories a load to the environment. Figure 1 shows the normalized potential impacts for all 500000 tons of waste annually managed. The majority of impacts originate from the Office, Commercial \& Institutional Waste, which constitutes about $73 \%$ of the municipal waste.

Global Warming impacts are very significant: a net load of 30000 person equivalents (PE) or about 230000 tons of $\mathrm{CO}_{2}$-equivalents emitted per year. The landfill is totally dominating this impact since collection and transport of the waste contribute less than 1000 PE (not shown). The impact is due to a load and a saving: the load is from $\mathrm{CH}_{4}$ escaping through the top cover of the landfill into the atmosphere about 54000 PEs - and a saving caused by the storage of biogenic carbon in the landfill beyond the 100year period considered - about 24000 PEs. Our estimate on the Global Warming impact seems to be more than three times higher when expressed in PE per tonne of waste landfilled than the estimate provided by Tulokhonova \& Ulanova (2013) using a "European Landfill" as representative of the landfill in Irkutsk. Actually Tulokhonova \& Ulanova (2013) used "inhabitant equivalents" without any specification; but we assume the equivalents are identical. This emphasizes the importance of using technologies modified to resemble the actual local conditions and not use only standard technologies from Europe. Tulokhonova \& Ulanova (2013) did not account for biogenic carbon bound in the landfill after 100 years and thus did not credit the landfill this saving. This should have been included in order to do the accounting mathematically consistent (Christensen et al, 2009).

The toxicity impacts are low (300 PEs), while Ozone Depletion (2800 PEs) and Ozone Formation (7100 PEs) are significant. Ozone Depletion is due to trace gases, in particular volatile chlorinated compounds (CFCs), escaping from the landfill and destroying the protective ozone layer of the stratosphere, while Ozone Formation is due to $\mathrm{CH}_{4}$ escaping from the landfill (about 5700PEs) and to nitro oxides from the combustion of diesel in trucks (about 1100 PEs).

Eutrophication represents nutrients discharged to surface waters and is estimated to a net load of approximately 175 PEs originating from phosphates associated with the bottle washing (300PE) and savings 
in virgin cardboard production due to recycling of paper (- $125 \mathrm{PE})$. The leachate migrating into the groundwater is with the current approach not ascribed any impact on surface water, since any phosphorous in the leachate is assumed to be retained in the subsoil before reaching any surface water bodies. This implicitly assumes that the groundwater as such is not a resource of high priority in the vicinity of the landfill. Where groundwater is an important resource, the impact of the leachate on the groundwater quality should be included.

\section{The current waste management system - new landfill}

As the current landfill soon will have no more capacity to receive the municipal waste from Irkutsk, we investigated how the environmental profile of the waste management system would develop if a new and modern landfill was built with gas and leachate collection and treatment. Figure 2 shows the environmental impacts from a system similar to the one descried above, but now with a new sanitary landfill.

The net Global Warming contribution is now a saving of the order of 100000 tons $\mathrm{CO}_{2}$-equivalents per year. The landfill is still the dominating factor: The direct emission of $\mathrm{CH}_{4}$ is significantly reduced to 11 000 PEs, the savings from the stored biogenic carbon beyond 100 years is unaltered, while using the gas for electricity production provides savings of $9000 \mathrm{PE}$, since otherwise coal would have been used for production of the same amount of electricity. The amount of uncollected methane is still significant and it should be considered to continue collection of the landfill gas beyond the 30 years used in the modeling. Since the degradation rates for the organic factions in the waste used in the modeling are for cold and semi-dry climates, the gas generation will take place for very long time, and a 30 year collection period as often assumed in Europe may not suffice.

The toxicity impacts are a net saving due to the energy produced from the landfill gas (-1000 PEs), while Ozone Depletion (1800 PEs) and Ozone Formation (3000 PEs) are reduced to half due to less landfill gas escaping to the atmosphere.

The Eutrophication impact increased with the new landfill because leachate is collected, treated and discharged to surface water. Although the leachate treatment is efficient, some phosphorus still is discharged to the surface water (1550 PE) contributing to surface water eutrophication. This is though counterbalanced by savings from avoided eutrophication due to landfill gas producing electricity that otherwise would have been produced from coal burning (-4100 PE), giving a net effect of -2100 PE (saving).

\subsection{Sensitivity analysis}

To assess the robustness of the system a number of sensitivity analyses was carried out to assess the importance of some of the parameters used in the modeling. As was seen from Figure 1 and 2 the largest impact was global warming so we show the results only for this impact category. All the sensitivity results are compared with the results for the new landfill. The sensitivity analysis focused on the following parameters:

- Gas generation rate. In the modeling we assumed low degradation rates considered applicable to cold and semi-dry regions, this was changed to temperate climate gas generation rates with an average value (first order degradation constant) of $0.38 \mathrm{yr}^{-1}$

- Methane oxidation in the top cover. Due to the lower flux in the new landfill we assumed a topcover oxidation of $50 \%$ of the non-collected methane. We changed this to $20 \%$ so it was comparable to oxidation in the old landfill 
- Gas collection period. The collection period was changed from 30 years to 45 years, which means that a smaller amount of fugitive methane is released

The results of the sensitivity analysis are presented in Figure 3.

The impact of using standard decay rates instead of those for cold and semi-dry regions is minor with a net difference of $4 \%$. This is due to slightly more degradable matter decaying in a 100 year timeframe, which means slightly less carbon is stored in the landfill after this time. Furthermore due to the faster decay more gas will be collected in the 30 year collection period which means that less methane will be released through the top cover and instead be used for electricity production.

The importance of the top cover oxidation rate can be seen to be critical for the impact of the landfill. The impact of the release of methane with a $20 \%$ top cover oxidation efficiency is about 40000 tons $\mathrm{CO}_{2}-$ equivalents per year higher that with the $50 \%$ oxidation efficiency assumed for the new sanitary landfill. This highlights that it is crucial to control the methane escape, either by enduring efficient oxidation in the top cover or by collection of the gas; in the latter case it is of less importance how the methane is treated (flared or energy recovery). With no active collection system the flux through the top cover will be higher, and therefore the oxidation efficiency will drop as well.

Finally it was found that an extension of the active gas collection period only gave a minor improvement of the system, a $6 \%$ better net performance wrt. Global Warming. This highlights that the majority of the degradable matter is degrading in the first 30 years of the landfills lifetime, and extension of the system has minor importance.

\section{Conclusion}

The inventory data available for the Irkutsk waste management system are sufficient for performing an environmental assessment of the current system, since almost all waste is landfilled. However, it is recommendable to establish separate data on amounts and composition of the three main sources of municipal waste: Household Waste, Commercial Waste and Office \& Institutional Waste. This information will be crucial for the development of new and alternative waste management systems with a higher focus on recycling by means of source separation of recyclables.

The potential impact of Global Warming is by far the most significant load from the current waste management system. It corresponds to a net annual contribution of 230000 tons of fossil $\mathrm{CO}_{2}$. The landfill with the emission of methane is the source. The landfill also contributes to Ozone Depletion and to Ozone Formation from the emission of landfill gas. Combustion of diesel in collection and transport vehicles causes only minor contribution to the impact from the current waste management system. From an environmental point of view, the current waste management system does not match the performance of modern European waste management systems. This suggests that there may be room for improvement in the current system although conclusions cannot be transferred from one region to another due to differences in waste composition, the energy system and the recycling possibilities.

Introduction of a modern landfill with gas and leachate management systems as the old landfill runs out of capacity can definitely improve the environmental performance of the Irkutsk waste management system. Reduction of the direct emissions and the recovery of energy from the landfill gas can reduce the Global Warming impact, so that it actually results in a net saving wrt. Global Warming corresponding to 100000 tons of $\mathrm{CO}_{2}$-equivalents per year. As the sensitivity analysis showed, it is crucial 
to make sure the flux of landfill gas through the top cover is lowered by collecting the gas. If the oxidation efficiency of the top cover is lowered from $50 \%$ to $20 \%$ it means that the new landfill will release another 40000 tons of $\mathrm{CO}_{2}$-equivalents per year. It may also be worth considering a longer collection period than 30 years for the gas since the cold climate in Siberia are expected to cause a slow generation of gas. By increasing the collection and utilization of the gas to 45 years the direct Global Warming potential impact from the landfill can be reduced with an additional $10 \%$ for the new landfill.

The current waste management system in the Irkutsk region does not perform well from an environmental point of view. The uncontrolled landfill is the main contribution to Global Warming impact. Although the introduction of modern landfill technology can reduce this impact significantly, it is worth considering other waste management systems with more focus on recycling and less use of landfill. This is the subject of a following paper (Starostina et al., 2013).

\section{Acknowledgement}

Vlada Starostina would like to thank the EU Erasmus-Mondus Programme for a scholarship supporting her in this work and financing her stay in Europe.

\section{References}

Christensen, T H, Bhander, G S, Lindvall, H, Larsen, A W, Fruergaard,T, Damgaard, A, Manfredi, S, Boldrin, A, Riber, C \& Hauschild, M Z (2007): Experience with the use of LCA-modelling (EASEWASTE) in waste management. Waste Management and Research, 25, 257-262.

Christensen, T H, Gentil, E, Boldrin, A, Larsen, A W, Weidema, B P \& Hauschild, M Z (2009): C balance, carbon dioxide emissions and global warming potentials in LCA-modeling of waste management systems. Waste Management and Research, 27, 707-715.

Cencic, O \& Rechberger, H (2008): Material flow analysis with software STAN. Journal of Environmental Engineering and Management, 18, 3-7.

Clavreul J, Guyonnet D \& Christensen T H (2012): Quantifying uncertainty in LCA-modelling of waste management systems. Waste Management, 32, 2482-2495.

De la Cruz, F \& Barlaz, M.(2010): Estimation of waste component-specific landfill decay rates using laboratory-scale decomposition data. Environmental Science \& Technology, 44, 4722-4728.

Den Boer, J, Den Boer, E \& Jager, J (2007) LCA-IWM: A decision support tool for sustainability assessment of waste management systems. Waste Management 27, 1032-1045.

DEPAI (2007): The integrated plan of a sanitary cleaning of Irkutsk. Department of Environmental Protection of Administration of Irkutsk, Irkutsk (In Russian).

European Commission (2011)-Joint Research Centre - Institute for Environment and Sustainability: International Reference Life Cycle Data System (ILCD) Handbook- Recommendations for Life Cycle Impact Assessment in the European context. First edition November 2011. EUR 24571 EN. Luxemburg. Publications Office of the European Union; 2011

Gentil, E, Damgaard, A, Hauschild, M Z, Finnveden, G, Eriksson, O, Thorneloe, S, Kaplan, P O, Barlaz, M A, Muller, O, Matsui, Y., Li, R \& Christensen,T H (2010): Models for waste life cycle assessment: Review of technical assumptions. Waste Management, 30, 2636-2648. 
Gonopolsky, A, Nikolaikin, N, Mitashova, T \& Kushnir, K (2009): The development of a technology for cleaning and decontamination of MSW landfill leachate. Environmental Project No 02.515.11.5085. Moscow State University of Environmental Engineering, Moscow, Russia (In Russian)

Kirkeby, J T, Birgisdóttir, H, Hansen, T L, Christensen, T H, Bhander, G S \& Hauschild, M Z (2006a): Environmental assessment of solid waste systems and technologies: EASEWASTE. Waste Management and Research, 24, 3-15.

Larsen, A W, Merrild, H, Møller, J \& Christensen, T H (2010): Waste collection systems for recyclables: An environmental and economic assessment for the municipality of Aarhus (Denmark). Waste Management, 30, 744-754.

Larsen, A W, Vrgoc, M, Christensen, T H \& Lieberknecht, P (2009): Diesel consumption in waste collection and transport and its environmental significance. Waste Management and Research, 27, 652-659.

Laurent, A, Olsen, S I, Hauschild, M Z (2011a): Normalization in EDIP97 and EDIP2003: updated European inventory for 2004 and guidance towards a consistent use in practice. International Journal of Life Cycle Assessment, 16, 401-409.

Laurent, A, Lautier, A, Rosenbaum, R K, Olsen, S I, Hauschild, M Z (2011b): Normalization references for Europe and North America for application with USEtoxTM characterization factors. International Journal of Life Cycle Assessment, 16, 728-738

Manfredi,S.\& Christensen,T H (2009): Environmental assessment of solid waste landfilling technologies by means of LCA-modeling. Waste Management, 29, 32-43.

MNREIR (2012): About a situation and protection of the environment in Irkutsk region: year 2011. Ministry of Natural Resources and Environment of the Irkutsk Region, Irkutsk (In Russian).

MOI (2008): The adoption of the norms of an annual municipal waste generation in the city of Irkutsk. Municipal Ordinance of Irkutsk, Irkutsk (In Russian).

Potapov, P, Pupyrev, E \& Potapov, A(2004): Methods of localization and treatment of MSW landfills leachate. Association of Engineering Universities, Moscow, Russia. (In Russian)

Riber, C, Petersen, C \& Christensen, T H (2009): Chemical composition of material fractions in Danish household waste. Waste Management, 29, 1251-1257.

Rosenbaum, R K, Bachmann, T M, Gold, L S, Huijbregts, M A J, Jolliet, O, Juraske, R, Köhler, A, Larsen, H.F, MacLeod, M, Margni, M McKo,ne, T E, Payet, J, Schuhmacher, M, van de Meent, D, Hauschild, M Z (2008): USEtox - The UNEP SETAC toxicity model: recommended characterisation factors for human toxicity and freshwater ecotoxicity in Life Cycle Impact Assessment. International Journal of Life Cycle Assessment, 13, 532-546

ROSHYDROME (2012): Peculiarities of climate in the Russian Federation in 2011. Federal Service for Hydrometeorology and Environmental Monitoring, Moscow (In Russian).

Scheutz, C, Kjeldsen, P, Bogner, J, De Visscher, A, Gebert, J, Hilger, H, Huber-Humer, M, Spokas, K (2009): Microbial methane oxidation processes and technologies for mitigation of landfill gas emissions. Waste Management \& Research, 27, 409-455.

Starostina, V, Damgaard, A, Rechberger, H, Møller, J \& Christensen, TH (2013): Waste management in the Irkutsk Region, Siberia, Russia: Environmental assessment of alternative development scenarios. To be submitted. 
Tulokhonova, A \& Ulanova, O (2013): Assessment of municipal solid waste management scenarios in Irkutsk (Russia) using a life cycle assessment - integrated waste management model. Waste Management and Research, 31, 475-484

Vergara, S E, Damgaard, A \& Horvath, A (2011): Boundaries matter: Greenhouse gas emission reductions from alternative waste treatment strategies for California's municipal solid waste. Resources, Conservation and Recycling, 57, 87-97

Zhao, Y, Christensen, T H, Lu, W, Wu, H \& Wang, H (2010): Environmental impact assessment of solid waste management in Beijing City, China. Waste Management, 31, 793-799

Zomarev, A (2007): Sanitary-hygienic monitoring of MSW landfills. Perm National Research Polytechnic University, Perm, Russia. (In Russian)

Table 1: Environmental impact categories and normalization references used in the LCA impact assessment. References given are first to method, next to normalization references.

\begin{tabular}{|l|l|l|l|l|}
\hline Impact category & Methode & Unit & Amount & Reference \\
\hline Climate change & IPCC2007 & $\mathrm{kg} \mathrm{CO}_{2}$-Eq & 7730 & $\begin{array}{l}\text { IPCC (2007) } \\
\text { Laurent et al., 2011a }\end{array}$ \\
\hline Ozone depletion & EDIP97 (WMO) & $\begin{array}{l}\text { kg CFC-11- } \\
\text { Eq }\end{array}$ & 2.05E-2 & $\begin{array}{l}\text { Wenzel et al., 1997 } \\
\text { Laurent et al., 2011a }\end{array}$ \\
\hline Acidification & ReCiPe & $\mathrm{kg} \mathrm{SO}_{2}$-Eq & 49.9 & $\begin{array}{l}\text { Van Zelm et al., 2008 } \\
\text { Sleeswijk et al, 2008 }\end{array}$ \\
\hline Eutrophication, terrestrial & $\mathrm{CML}$ & $\mathrm{kg} \mathrm{NOx-Eq}$ & 356 & $\begin{array}{l}\text { Guinée et al., 2002 } \\
\text { Huijbregts et al., 2013 and CML, 2013 }\end{array}$ \\
\hline Eutrophication, aquatic & ReCiPe & $\mathrm{kg}$ P-Eq & 0.69 & $\begin{array}{l}\text { Van Zelm et al., 2008 } \\
\text { Sleeswijk et al, 2008 }\end{array}$ \\
\hline Photochemical ozone formation & ReCiPe & $\mathrm{kg} \mathrm{NMVOC}$ & 52.9 & $\begin{array}{l}\text { Van Zelm et al., 2008 } \\
\text { Sleeswijk et al, 2008 }\end{array}$ \\
\hline Ecotoxicity (freshwater) & USEtox & CTUe & 5060 & $\begin{array}{l}\text { Rosenbaum et al, 2008 } \\
\text { Laurent et al., 2011b }\end{array}$ \\
\hline Human toxicity, cancer effects & USEtox & CTUh & $3.25 E-5$ & $\begin{array}{l}\text { Rosenbaum et al, 2008 } \\
\text { Laurent et al., 2011b }\end{array}$ \\
\hline Human toxicity, non- cancer effects & USEtox & CTUh & $8.14 E-4$ & $\begin{array}{l}\text { Rosenbaum et al, 2008 } \\
\text { Laurent et al., 2011b }\end{array}$ \\
\hline
\end{tabular}

${ }^{1}$ Calculated based on population in EU-15 1995 assumed to: 380 million, and the total value for 1995: 1.4E+11 kg PO43- eq. / yr 
Table 2: Composition of MSW in Irkutsk (Material fractions are measured; composition obtained from the literature, Riber et al. 2009)

\begin{tabular}{|c|c|c|c|c|}
\hline \% Wet weigth & $\begin{array}{l}\text { MSW } \\
\text { Waste }\end{array}$ & $\begin{array}{c}\text { Heating } \\
\text { value, LVH } \\
\text { (MJ/kg ww) }\end{array}$ & $\begin{array}{c}\text { Ash } \\
\text { (\%Ash/TS) }\end{array}$ & $\begin{array}{c}\text { Volatile } \\
\text { solids } \\
\text { (\%VS/TS) }\end{array}$ \\
\hline Organics & 30 & & & \\
\hline Vegetable food waste & 25.0 & 2.5 & 5.2 & 94.8 \\
\hline Animal food waste & 5.0 & 9.2 & 8.7 & 91.3 \\
\hline Paper & 23.5 & & & \\
\hline Newspaper & 1.5 & 14.6 & 8.2 & 91.8 \\
\hline Magazines & 3.0 & 10.6 & 34.0 & 76.0 \\
\hline Office paper & 1.3 & 11.2 & 20.7 & 87.8 \\
\hline Dirty paper & 6.7 & 13.2 & 8.9 & 91.1 \\
\hline Cardboard & 11.0 & 12.2 & 14.0 & 86.0 \\
\hline Glass & 11.3 & & & \\
\hline Glass-clear & 5.7 & -0.3 & 100 & 0 \\
\hline Glass-green & 2.8 & -0.1 & 100 & 0 \\
\hline Glass-brown & 2.3 & -0.1 & 100 & 0 \\
\hline Glass-other & 0.5 & -0.2 & 100 & 0 \\
\hline Plastics & 15.8 & & & \\
\hline Bottles & 3.0 & 32.5 & 6.1 & 93.9 \\
\hline Soft plastic & 8.0 & 34.1 & 4.4 & 95.6 \\
\hline Hard plastic & 2.4 & 36.1 & 2.2 & 97.8 \\
\hline Non-recycable & 2.4 & 29.2 & 5.5 & 94.5 \\
\hline Textile & 7 & 18.5 & 3.6 & 96.4 \\
\hline Metal & 2.6 & & & \\
\hline Steel containers & 1.0 & -0.3 & 100 & 0 \\
\hline Aluminum containers & 0.4 & -0.2 & 100 & 0 \\
\hline Other of metal & 1.2 & -0.2 & 100 & 0 \\
\hline Rubber & 1.2 & 27.2 & 9.7 & 90.3 \\
\hline Leather & 1 & 22.9 & 12.6 & 87.4 \\
\hline Wood & 1 & 15.6 & 10.0 & 90.0 \\
\hline Others & 6.6 & -0.8 & 97.7 & 2.3 \\
\hline Total & 100 & & & \\
\hline
\end{tabular}


Table 3: Estimated composition (\% wet weight) of Household Waste and a combine fraction Commercial, Office \& Institutional Waste .

\begin{tabular}{|c|c|c|}
\hline \% Wet weight & $\begin{array}{l}\text { Household } \\
\text { Waste }\end{array}$ & $\begin{array}{c}\text { Commercial, Office \& } \\
\text { Institutional Waste }\end{array}$ \\
\hline Organics & 45 & 24 \\
\hline - $\quad$ Animal & 7.5 & 4 \\
\hline - $\quad$ Vegetable & 37.5 & 20 \\
\hline Paper & 15 & 27 \\
\hline - $\quad$ Newspaper & 4.1 & 0.5 \\
\hline - $\quad$ Magazines & 10.1 & 0.5 \\
\hline - $\quad$ Office Paper & 0.1 & 1.7 \\
\hline - $\quad$ Dirty paper & 0.4 & 9.1 \\
\hline - $\quad$ Cardboard & 0.3 & 15.2 \\
\hline Glass & 12 & 11 \\
\hline - Clear & 6.9 & 5.3 \\
\hline - $\quad$ Green & 3.0 & 2.8 \\
\hline - $\quad$ Brown & 2.1 & 2.3 \\
\hline - $\quad$ Other & 0 & 0.6 \\
\hline Plastics & 8.5 & 18.5 \\
\hline$-\quad$ Soft & 1.5 & 10.3 \\
\hline - Hard & 1.5 & 2.7 \\
\hline - $\quad$ Bottles & 1.6 & 3.7 \\
\hline - $\quad$ Non-recyclable & 3.9 & 1.8 \\
\hline Textile & 7 & 7 \\
\hline Metal & 3 & 2.5 \\
\hline - $\quad$ Steel & 0.9 & 1.2 \\
\hline - $\quad$ Aluminum & 0.8 & 0.2 \\
\hline - $\quad$ Other metal & 1.3 & 1.1 \\
\hline Rubber & 1 & 1.3 \\
\hline Leather & 1 & 1 \\
\hline Wood & 0.5 & 1.2 \\
\hline Others & 7 & 6.5 \\
\hline Total & 100 & 100 \\
\hline
\end{tabular}


Table 4: Firs order decay rate (k) used for degradable fractions in study, based on De la Cruz \& Barlaz (2010),

\begin{tabular}{|c|c|}
\hline \multicolumn{1}{|c|}{ Material } & Decay rate $\left(\mathbf{y r}^{-\mathbf{1}}\right)$ \\
\hline Average & 0.020 \\
\hline Organics & \\
\hline$-\quad$ Animal food waste & 0.072 \\
\hline$-\quad$ Vegetable food waste & 0.072 \\
\hline$-\quad$ Wood & 0.008 \\
\hline Paper & \\
\hline$-\quad$ Cardboard & 0.010 \\
\hline$-\quad$ Dirty paper & 0.016 \\
\hline$-\quad$ Magazines & 0.061 \\
\hline$-\quad$ Newspaper & 0.017 \\
\hline$-\quad$ Office Paper & 0.015 \\
\hline Other & \\
\hline$-\quad$ Textiles & 0.015 \\
\hline
\end{tabular}




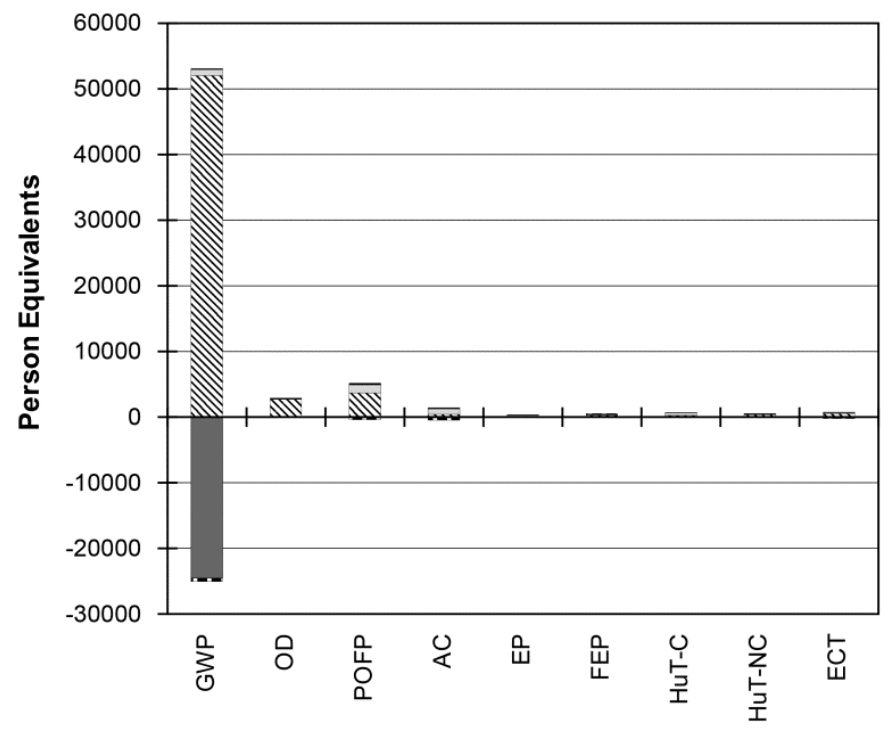
IIII Recycling
Carbon storage in landfill
Transport
Collection
NIV Landfill

Figure 1: Environmental impacts (person equivalents) estimated for the Irkutsk municipal waste management system handling 500000 tons of municipal waste yearly (Old "Alexandrovsky" landfill). (GWP: Global Warming; OD: Ozone Depletion; POFP: Photochemical Ozone Formation: AC: Acidity, EP: Eutrophication; terrestrial; FEP: Freshwater Eutrophication; HuT-C: Human Toxicity -Carcinogen, HuT NC: Human Toxicity - Non-carcinogen, ECT: Ecotoxicty). 


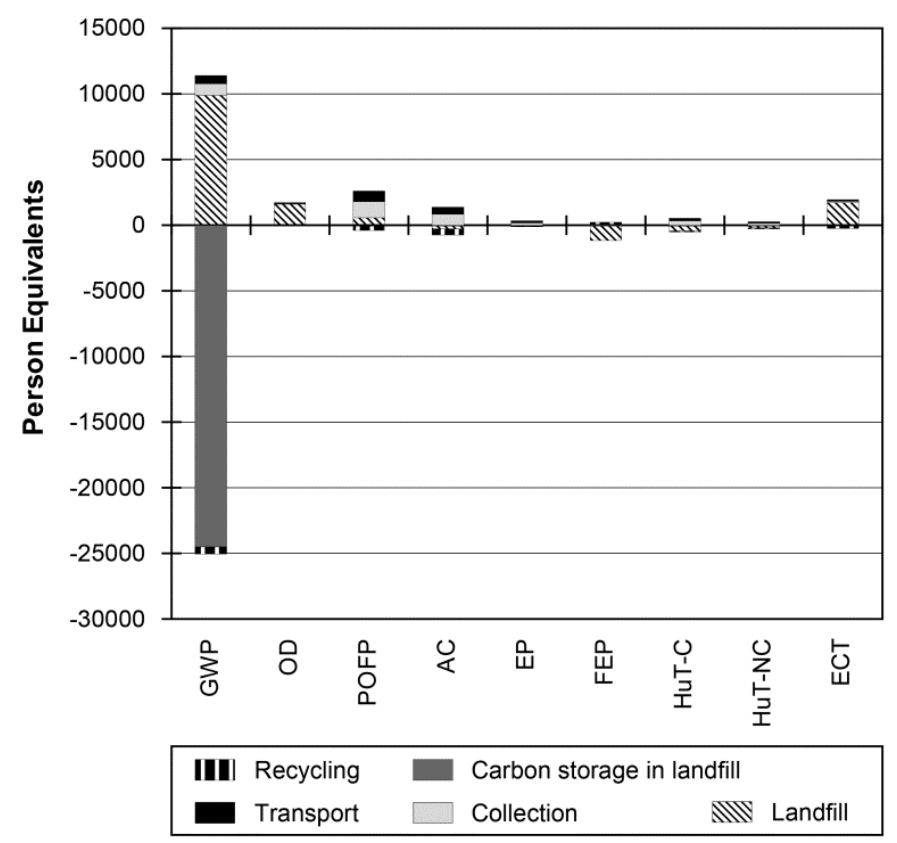

Figure 2: Environmental impacts (person equivalents) estimated for the Irkutsk municipal waste management system handling 500000 tons of municipal waste yearly (New sanitary landfill). (GWP: Global Warming; OD: Ozone Depletion; POFP: Photochemical Ozone Formation: AC: Acidity, EP: Eutrophication; terrestrial; FEP: Freshwater Eutrophication; HUT-C: Human Toxicity -Carcinogen, HuT NC: Human Toxicity - Non-carcinogen, ECT: Ecotoxicty). 


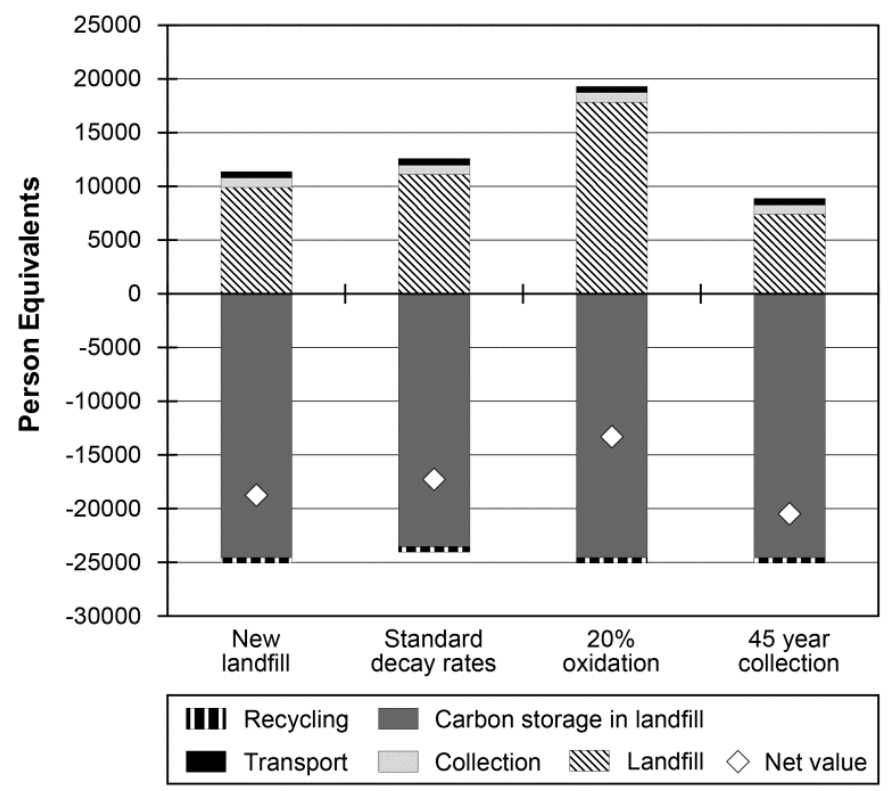

Figure 3: Global Warming impact (GWP, net; person equivalents) estimated for the Irkutsk municipal waste management system handling 500000 tons of municipal waste yearly. The shown data are for the new sanitary landfill cold-climate degradation rates and the same landfill with standard degradation rates, $20 \%$ oxidation of fugitive gas in top cover, and 45 years of gas collection in lieu of the standard 30 years. The rhomb represents the net value (load minus saving). 